\title{
Diction Form and Language Style in Sabda Luka Novel By S. Gegge Mappangewa
}

\author{
Herianah $^{1}$ and Jusmianti Garing ${ }^{2}$ \\ email: herianah606@gmail.com¹, garingjusmianty78@gmail.com²
}

Balai Bahasa Sulawesi Selatan, Talasalapang, Makassar ${ }^{1}$, Balai Bahasa Sulawesi Selatan, Talasalapang, Makassar ${ }^{2}$

\begin{abstract}
The research aims to describe the use of figurative language and diction in Sabda Luka's novel by S. Gegge Mappangewa. The research is a library study that uses qualitative descriptive methods using inventory, readinglistening, and noting techniques. The results show that Sabda Luka's novel has several figurative languages, including (1) comparative literature, (2) conflicting language style, (3) interrelated linguistics, and (4) repetitive linguistic style. The diction has been found using regional languages (Buginese) and foreign languages (English and Arabic). The author uses the term Buginese in addressing his characters, namely Daeng, Nenek Mallomo, Dewata SeuWa (Sang Hyang Widi), calabai, tabbere bajaE, sarapo, and walasuji. Furthermore, foreign words are using stop time, which sources from English. Meanwhile, the Arabic term used is siratal mustakim. In addition to the terms, regional and international languages refer to greetings in Sabda Luka's novel.
\end{abstract}

Keywords: stylistic, figurative language, diction, Sabda Luka novel

\section{Introduction}

A novel is a fictional prose narrative of a certain length containing intrinsic elements and an overall imaginative characteristic [1]. [2] conveyed that a story is not to be read in one sitting, as in its characteristic length, the novel requires sufficient opportunity to develop its characters over time. Nevertheless, a novel story presents an in-depth life story along with extraordinary events in a believable manner. What distinguishes poetry from fiction like short stories and novels in the form and use of the language. In a short story or novel, a sentence must be written intact and ends with punctuation; poetry had the freeway [3]. Fictions are categorized as fiction prose, as they consist of imagination or something that has never been. For general readers, the categorization was declaring that any form of fiction created with a specific purpose [4]. A novel consists of minimal symbol units that have a meaning. A story had, such as a vocabulary and sensual idioms, included simile, metaphor, and metonymy [5]. Every author has a unique style in writing his/her work. The unique sets of characteristics and patterns in their use of language distinguishing them from other authors.

Regard to style, literature was employed literary language as a medium to achieve

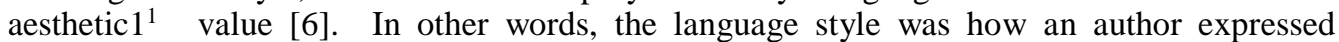
whatever they want to say. [7] explains that speech style is (1) a person taking advantage of the richness of a language, whether in speech or writing, (2) use of a variety of individual

${ }^{1}$ Aesthetic is the value of beauty attached to work. 
words to achieve a particular effect, and (3) the sum of the characteristics of the language of a group of authors. [8] proposed that speech style was the formal language employed for improving efficacy by introducing and comparing specific concepts with other more general ideas. Furthermore, [8], generally divided into four categories of speech styles, namely comparison, contradiction, connection, and repetition. These speech styles are used by authors to compose their thoughts using the medium of language in beauty and harmony and lend nuance that stimulates the reader's intellect and emotions. [8]. Beauty language used in a story, such as a novel is depending on word choices (diction) from the author.

Word choice is related to the proper option of words for expressing one's thoughts and feelings. Well-chosen words will help one accurately show what they wish to say. The use and choice of words constitute a primary aspect in writing letters, as words are the units of meaning that affect the formal linguistic structure of a work. Thus, fitting word choice is a necessity. Proper word choice ${ }^{2}$ will achieve high poetic and aesthetic value. [9] summarizes three main facts concerning diction. First, word choice or language encompasses how words are used to express the idea, how to shape groups of words properly or use expressions properly, and which style is best to apply for a given situation. Second, word choice or diction is the ability to differentiate between nuances of meaning and ideas one wishes to communicate, and the ability to find the appropriate form for the situation and tastes of one's audience. Third, the proper word choice is only made possible by the mastery of a treasury of vocabulary or information in a given language. Meanwhile, the lexicon of a language was defined as collecting all words belonging to that language. A lexical choice means the entirety of lexical decisions made in a literary text [10]. Thus, diction also refers to the correctness of the lexical choice. In other words, the choice of said words has gone through specific considerations to achieve a particular effect, i.e., a precise or aesthetic impact [7].

Based on this line of reasoning, this study focuses on the novel of author S. Gegge Mappangewa, namely Sabda Luka, with the scope of research being language analysis, examining the unique style and word choice, or diction in the novel Sabda Luka by S. Gegge Mappangewa. The study's goal is the documentation and publication of an article describing the language, word choice, and diction of Sabda Luka by S. Gegge Mappangewa. Sabda Luka is a novel of the human relationship within the family and its complex environment, mainly due to the conflict caused by cultural and religious differences ${ }^{3}$. This novel tells a story about twin brothers, Vito and Vino, who have separated from one another at a very young age. Their parents divorced because of cultural differences. Their grandfather rejected their father, Ilham, for his faith in the local Tolotang religion, making him leave his family. Vito lives with his mother, and Vino stays with his father, Ilham. One day, after he can no longer stand his longing for his father, Vito finally leaves the village and begins searching for his father in Perrinyameng, Amparita, about a dozen kilometers from his community on the mountain. This novel is a story about a junior high school student looking

\footnotetext{
2 The choice of words or diction is selected and arranged in such away. Thus, its meaning gives rise to aesthetic imagination.

${ }^{3}$ The religious differences referred to in this novel, Mrs. Halimah is a Muslim, while her father (Ilham)

is a Tolotang adherent, even though they are both Buginese, who lives in Sidrap. Initially, Tolotang was recognized by the state as a belief stream called Lontara holy book. When the state only recognizes five religions, Tolotang gives three choices: Islam, Christianity, and Hinduism. They chose Hinduism on the pretext of tradition due to its having similarities with Hinduism. Thousands of them live in Amparita, the Capital of Tellu Limpoe Subdistrict, Sidrap Regency. They mingle with Muslims around them. Tolotang itself means the south. It is due to its area of origin located south of Sidenreng.
} 
for his family and the warmth of family when he lives in Cenrana, Panca Lautang, Sidenreng Rappang, South Sulawesi [11].

\section{Research Method}

This research is qualitative descriptive ${ }^{4}$ research. The source of this research is the novel Sabda Luka by S.Gegge Mappangewa, published by Media Kreasi Surakarta, February 2018 (1st ed.). Besides, this research also constitutes literary research and thus is conducted using data collection techniques such as listening, reading, and notetaking. Subsequently, data analysis was conducted systematically on data relevant to the variables researched. The steps in data analysis taken for this research were (a) sorting through a data corpus from the novel Sabda Luka by S.Gegge Mappangewa based on facts regarding the language used, (b) data reduction, namely identification, selection, and classification of the data corpus, and (c) data presentation, namely the organization, tabulation, and analysis of the data, and its verification or summation, namely the drawing of hypotheses based on said data reduction and presentation.

\section{Result and Discussion}

\subsection{Speech Styles in Sabda Luka}

The analysis results show four speech styles that the author used in delivering the story and, therefore, makes that an interesting story to read and study for readers who love literature and language. Four speech styles used: relative speech style, conflicting speech style, connective speech style, and repetitive speech style.

\section{Comparative Speech style}

The comparative speech style consists of simile, metaphor, personification, antithesis, pleonasm, and tautology.

\section{Simile}

A simile is a speech style that directly compares two different things and showing similarities between them. The comparison itself is explicitly explained by the usage of words such as seperti (in English 'like '), ibarat (in English 'like '), laksana (in English 'as '), etc. The speech styles mentioned are using in the quotations from novel Sabda Luka below:

(1) Vito menyusuri sekolah dengan mata seperti rusa masuk kampung.

(Vito goes to school like a fish out of water.) (SL, 33). (20)

The data (1) finds a sentence using a simile, shown by the usage of the word seperti (in English 'like'). Simile in the sentence (1), when Vito disguises as Vino like a fish out of water, Vito goes to school in Samarinda, where his father lived, and meets his new friends.

\section{Metaphor}

\footnotetext{
${ }^{4}$ Qualitative research is a data source in the form of natural settings. Data is collected directly from the real environment as the subjects in daily activities carry it out.
} 
Metaphor is a speech style that compares two things to create a living mental impression even though it's not explicitly expressed, by the usage of words such as ibarat (in English 'like '), umpama (in English 'as '), etc. Metaphorical speech styles can find in the paragraph below.

(2) Dia sering berangan, sayap-sayap yang dulu pernah Bu Maulindah tumbuhkan sebelum berangkat ke Jepang, suatu saat akan berbulu sempurna dan menerbangkannya melintasi gunung dan perbukitan yang mengelilingi Pakka Salo. (He often imagined the little wings that Mrs. Maulindah used to plant on his back before she left to Japan, one day would spread ideally and enable him to fly across the mountains and the hills surrounding Pakka Salo.) (SL, 10) (20)

In data (2) is a symbolic speech style that implicitly contains comparison even without using related words. It shows in Irfan's character, who often daydreams because Mrs. Maulindah's motivations encourage him to achieve his goals. The motivation is a little wing that one day spread perfectly and enables him to fly as high as possible. However, in those sentences, explicit comparative words are not used, but the comparison is implicit.

\section{Personification}

Personification speech style is a speech style that attributes human qualities to an animal, object, or abstraction. In the quotation from the novel Sabda Luka by S. Gegge Mappangewa ${ }^{5}$ below is found an example of personification:

(3) Vito menghilang di balik pintu kamar. Perpisahan menganga lagi. Rindu datang mengetuk-ngetuk. Luka datang menggores-gores.

(Vito disappears behind the bedroom door. Separation opens its mouth full. The longing comes knocking. The wound comes scratching.) (SL, 6) (20)

In data (3) is found the usage of personification speech style as shown in the phrase the longing comes knocking like a person. It also found in the expression of the wound that comes scratching. This speech style treats the word longing and wound like a person, possessing human attributes.

\section{Antithesis}

Antithesis is a speech style that refers to the juxtaposition of opposing or contrasting ideas

(4) Kamaruddin juga dulu kemayu, tapi bisa berubah menjadi sosok lelaki kekar karena ada keinginan dari dalam, jawabannya masih sama, calabai bukanlah takdir. Dia menggeleng lagi.

(Kamaruddin was also previously a kemayu (effeminate male), but he could turn into a macho man because of his strong will, the answer remained the same being, a calabai (shemale) was not his fate. Once again, he found himself shaking his head).

In data (4) is found an antithesis speech style. The sentence contains word kemayu, which means an effeminate male in contrast to a macho man. The word kemayu describes how Kamaruddin looks like an effeminate male, but then he changes into a macho man like his father always wanted. People that live around the Pakka Salo area used to call kemayu man as a calabai (shemale).

\section{Pleonasm and Tautology}

\footnotetext{
${ }^{5} \mathrm{~S}$. Gegge Mappangewa is one of the authors who are relatively active in South Sulawesi, who poured a lot of his work with the characteristics of the locality of South Sulawesi, particularly the ethnic Bugis.
} 
Pleonasm, or tautology, is a reference using more words than required to state an idea. A source is calling pleonasm when it removes the redundancy of words, but the meaning remains intact. On the other hand, a reference is calling tautology when the redundant statements contain a repetition of another word. The quotation from the novel Sabda Luka below has shown a pleonasm speech style.

(5) Kamarudddin memeluk ibunya dengan dekapan yang eratnya seolah tak bisa terlepas.

(Kamaruddin hugs his mother with a strong hug as if it couldn't remove) (SL, 250) Pleonasm speech style showed in data (5) is contained in the clause with a strong hug as if it couldn't remove. That clause has included an overabundance of words next, the sentence Kamaruddin hugs his mother, can still be understood without adding more clause like, with a strong hug as if it couldn't remove. Data (5) indicates a meeting between Kamaruddin and his mother, who is in jail, that he hasn't seen in a very long time. Kamaruddin has imprisoned after he murdered Mr. Kambu, who almost harassed Kamaruddin's wife, Tiara. In the next quotation, shows a tautological speech style taken from Sabda Luka.

(6) Jadi dia berusaha untuk ikhlas, membiarkan luka, doa, dan maaf itu mengubur dendamnya. (SL, 7).

(So, she resolved to let it go, allowing the pain, prayer, and forgiveness to overcome her need for revenge. (SL, 7))

Tautological speech style in data (6) is marked by a redundancy of words, as seen in the sentence so, she resolved to let it go, allowing the pain, prayer, and forgiveness to overcome her need for vengeance. This sentence is a redundant clause, namely allowing the grief, prayer, and forgiveness to overcome her need for revenge, which is unnecessary with she resolved to let it go.

\section{Conflicting speech style}

Speech styles of conflict found in the novel Sabda Luka are hyperbole, oxymoron, and climax.

\section{Hyperbole}

Hyperbole speech style shows in the quotation from the novel Sabda Luka below.

(7) "Terus Alauddin? Bukankah saya selama ini dikenal sebagai professo pecopeco?".

(Then what about Alauddin? All this time, I've known as professor peco-peco, haven't I?) (SL, 80)

Hyperbole is figures of speech in data (7) shown in the phrase professor peco-peco. The professor is a degree for a person who finished his doctoral study at the university. In Buginese, ресо-ресо ${ }^{6}$ means chili sauce made from pepper, tomato, and salt mashed together in traditional mashing tools. However, in this novel, Alauddin is skilled in building a delicious chili sauce, given him an exaggerated title as professor cobe-cobe.

\section{Oxymoron}

\footnotetext{
${ }^{6}$ Peco-Peco is Buginese typical food. Buginese people are naming as sambal made by teasing with a stone mortar.
} 
Oxymoron is a speech style that combines contradictory terms by using opposite words in the same phrase [13]. An example in the novel Sabda Luka containing oxymoron speech style is:

(8) "Kamu harus bersyukur, Allah telah mempertemukanmu dengan ayahmu. Cuma lain kali jika pergi menemui ayahmu, pulang sesuai dengan janjimu pada mamamu. Kasihan mamamu, mondari-mandir mencari kabar tentangmu

"You have to be thankful. Allah has reunited you with your father. But next time, if you went to see your father again, go home at the exact time as you have promised your mother. She's very concerned about you. (SL, 31)

Contradictory speech style is shown in the quotation above, as seen in the phrase "if you went to see your father" in contrast with "go home at the exact time as you have promised your mother." Therefore, the sentences in data (8) contain two contradictory things. In the sentence above, Vito advised Mr. Amin so that Vito can be fair towards both his father and mother, who have divorced.

\section{Climax}

The climax is a speech style that contains ideas that put in order of increasing importance (13). The example of climax speech style in the novel Sabda Luka is

(9) Tiba di sekolah langsung mengambil air wudhu untuk salat Dhuha. Istirahat siang harus dibagi antara jam makan dan jam salat Dhuhur, lalu harus salat Asar berjamaah sebelum pulang.

(As soon as he made it to school, he immediately performed the ritual ablution before the Dhuha prayer. Lunch break time must divide into lunchtime and Dhuhur prayer, and then Ashar prayer in congregation, before going home) [20].

In data (9), an example of the climax speech style is marked by the increasing importance of the previous idea. It can be seen in the words Dhuha's prayer, Dhuhur prayer, and Ashar prayer. The three prayer times show the passage of time from the morning, noon, and afternoon.

\section{Connective Speech Style}

Connective speech styles found in the novel Sabda $L u k a^{7}$ are synecdoche and euphemism.

\section{Synecdoche}

Synecdoche is a speech style that used a word or phrase that refers to a part of something to stand in for the whole (part prototo) or using the whole to stand in for a portion (totem pro parte) [13].

(10) Meski statusnya kepala sekolah, Pak Bahtiar tak pernah memosisikan diri sebagai pemimpin bermodal telunjuk di sekolah.

Even though he's the principal of the school, Mr. Bachtiar is not the type of leader that spent his days pointing fingers. (SL, 116).

In data (10), a synecdoche speech style is found, which is a leader who spent his days pointing fingers. The meaning of the quoted sentence is a bossy leader, a leader who always leads to someone else to do the job, a leader with a delusion of grandeur. This

\footnotetext{
${ }^{7}$ Sabda Luka is a novel that tells of two twin brothers who were separated from childhood because of the divorce of his parents.
} 
definition is not suitable for Mr. Bahtiar because he is a friendly type of leader, and he also protects both students and teachers. This type of leader is the one that does not point fingers at anyone else and is instead an example for everyone.

\section{Euphemism}

Euphemism is a speech style that uses a mild or indirect word or expression as a substitute for words that considered to be too harsh, blunt, or unpleasant [13], in this novel, the euphemism speech style found in:

(11) Kamaruddin tetap pergi, mengikuti panggilan hatinya untuk menjadi calabai $^{8}$ perias pengantin.

(Kamaruddin would still leave, to follow his heart's calling to be a calabai and a makeup artist). (SL, 22).

In data (11), we have found a mild substitute for shemale, which is calabai. It's from Buginese, which means shemale or an effeminate male. In Buginese culture, the word calabai is considered a mild substitute for a harsh word such as shemale, which in Indonesian is called waria or bencong. In this case, event hough Kamaruddin is already married, and his wife is already pregnant. He can no longer resist his own heart's calling to become effeminate.

\section{Repetitive Speech style}

The only type of repetition speech style found in the novel Sabda Luka is epizeuxis. The quote contains epizeuxis, which is:

(12) Dia telah tua oleh penantian. Beribu cerita penantian telah dilakoninya hingga akhirnya dia berkesimpulan bahwa jika penantian sulit berbuah pertemuan, cukuplah berbunga kepastian.

(She's getting old waiting. Thousands of waiting have become parts of her story, and it makes her finally conclude that waiting would hardly pay off, certainly is enough for her.) (SL, 177).

In data (12), the repetition speech style is shown in the word waiting. In the paragraph above, the word waiting has been repeated three times. Waiting is the emphasized word. Then, Mrs. Halimah is getting old, waiting. Waiting for Ilham for so long and now the next waiting she has to endure is her son, Vito, that went to Samarinda to visit his father.

\subsection{Usage of Lexical Choice}

The lexical choice is applied by the author to describe the plot based on addressing words, the usage of the descriptive terms, the usage of foreign names, and the usage of geographical location names.

\section{Addressing Words}

In the novel, Sabda Luka found several addressing words that are characteristics of Buginese culture:

(13) Saya membayangkan, Daeng yang setua itu duduk di pelaminan, "Canda istrinya."

(I can imagine, Daeng that old sitting on the wedding bed. Says his wife, joking) (SL, 3).

\footnotetext{
${ }^{8}$ Calabai, as people say, is born as a male. However, his temperament is like a female.
} 
In data (13), the word Daeng usage, which originates from Buginese, means older brother or sister. The name Daeng ${ }^{9}$ has addressed both men and women. It is a token of respect for those directed. The other form of addressing words can find in the next quotation.

(14) Bedanya, kemarau abad ke-16 itu berakhir setelah Nenek Mallomo seorang penasihat kerajaan memberi hukuman mati kepada anaknya yang terbukti mencuri.

(The difference was, the drought in the 16th century was over, after Nenek Mallomo, a royal advisor sentenced his son to death for stealing) (SL, 128).

In data (14), the title Nenek Mallomo is a unique title for people of Sidenreng, which has given to a scholar or the royal advisor. Nenek Mallomo is known as a just figure in giving punishment or advice. Nenek Mallomo is an impartial figure. If the person is proven guilty, even if it is his son, he will still punish them according to the rule.

\section{The Usage of Local Terms}

The usage of addressing words in local names has founded in the next quote:

(15) Dia tak mau menanggung malu karena ketahuan calabai lalu tewas diamuk massa.

(She doesn't want to bear the shame when people find out that she is a calabai, and threatened to death) (SL, 95).

In data (15) is found a local name, which is calabai or calalai. This word is usually using to refer to a man whose behavior is feminine like a woman, either it's the way he talks or the way he dresses.

\section{The Usage of Foreign Terms}

Aside from local names, this novel is also founding in foreign words such as:

(16) Stop watch di leher Pak Aamin itu sebenarnya tidak selalu digunakan.... Menurutnya, kalau berkalung sempritan tanpa stopwatch, itu bukan guru Penjas, tapi tukang parker.

(The stopwatch around Mr. Amin's neck did not use that often. For him, if people only bring a whistle without a stopwatch, then they are not a PE teacher. They are a parking attendant) (SL, 106)

In data (16), a term of a foreign word is found, which is a stopwatch, referring to the timer that is usually used by PE teachers to track times or the number of students' movements in PE class. This tool is used by Mr. Amin when he teaches. Next is the other of a different term.

(17) Jika tahun lalu, Vino seperti laki-laki penuh dosa yang melintasi siratal mustaqim, kini tiba-tiba seperti malaikat bersayap yang sedikitpun tak takut jatuh.

(If last year Vino looked like a sinful person crossing the siratal mustaqim bridge, now he suddenly looked like a winged angel, not in the least afraid to fall) (SL, $38)$.

In data (17) is found Arabic words, siratal mustaqim, or the straight and narrow path. Words siratal mustaqim, is also known as a bridge in the afterlife that we need to cross one day to get to Heaven. In Islam, people who have done many good deeds are believed to be prepared to face the siratal mustaqim easily. On the other hand, it will be impossible for sinful people to cross it.

${ }^{9}$ Daeng is an expression of people who respected both men and women. Daeng is used only by Buginese-Makassarese people. 


\section{The Usage of Geographical Terms}

Aside from local and foreign words, in the novel, Sabda Luka is also found geographical terms such as:

(18) Irfan telah pulang ke rumahnya di Bukkere. Ayahnya mengizinkan asalkan tak bermalam di Pakka Salo.

(Irfan has gone home to Bukkere. His father allows him, but in one condition, he should not stay the night at Pakka Salo.) (SL, 63)

In data (18), geographical terms have shown the place mentioned in the story. This novel has introduced in the name of an area, Bukkere, a village in Pakka Salo, in Sidrap District, South Sulawesi. Bukkere is the birthplace of the character, Irfan, while Pakka Salo is where his school locates.

\section{Conclusion}

The novel Sabda Luka talks about the human relationship in the family and its complex environment. That complexity happens due to cultural and religious background within Buginese society, and the complexity is also supported by using language style. Language styles referred are relative (comparative) language style, conflicting language style, interrelated language styles, and repetitive language style. Those various of speech style found in this novel gives uniqueness in S. Gegge Mapangewa as an author with specific characteristics in his works. In addition, lexical choices based on terms or languages used, either from Buginese or foreign languages. The author uses three Buginese terms to address the characters, i.e., Daeng, Nenek Mallomo, and Dewata SeuWa (Sang Hyang Widi). The name Daeng is a title of kinship for the elderly in Buginese culture. The term Nenek Mallomo is an addressing head for scholars and royal advisors in Buginese society in Sidrap. Dewata SeuWa (Sang Hyang Widi) is an addressing word to refer to the titles PotatoE and Tolotang. Another Buginese term used in the novel is calabai, tabbere bajaE, sarapo, and walasuji. Besides Buginese words, the Sabda Luka is also found in foreign names, i.e., English and Arabic names. The English name is a stopwatch. The Arabic one is a siratal mustaqim. The Sabda Luka also uses geographical terms functioning, as the story's location in the Bugis homeland, such as Bukkere and Pakka Salo.

Acknowledgments. The researchers express gratitude and the highest appreciation to the people who provided the motivation, support, and advice when conducting this research. The most general appreciation goes to Dra. Zainab, M. Hum, as the Head of Balai Bahasa Sulawesi Selatan (Language Center of South Sulawesi), always provided the support and approval for conducting this study. Also, to the Regent of Sidrap District, that is giving a very gracious welcome to researchers. Our gratitude further goes to $\mathrm{S}$. Gegge Mappangewa as the author of the novel Sabda Luka, for the discussion during this research is conducted.

\section{References}

[1]. Jabrohim (Ed.). Teori Penelitian Sastra. Yogyakarta: Pustaka Pelajar; 2015. http://pustakapelajar.co.id/buku/teori-penelitian-sastra/

[2]. Dasril R, Atmazaki, Afnita. Penggunaan Gaya Bahasa Kiasan Novel Dalam Mihrab Cinta. Prodi Pendidik Bahasa dan Sastra Indonesia. 2013;1(2):535-43. https://doi.org/10.24036/1370-019883

[3] Anindita KA, Satoto S, Sumarlam. Diction in Poetry Anthology Surat Kopi by Joko Pinurbo as A Poetry Writing Teaching Material. Int J Act Learn. 2017; 2 (1): 39-49. 
https://doi.org/10.15294/ijal.v2i1.10602

[4]. Anshari. Hermeneutika sebagai Teori dan Metode. Jurnal Sawergading 2009; 15 (2): 187--192. https://dx.doi.org/10.26499/sawer.v15i2.54

[5]. Cummings L. Pragmatics A Multidisciplinary Perspective. George Square: Edinburgh University Press; 2005 . https://books.google.co.id/books?id=0TNGAQAAQBAJ\&pg=PR4\&lpg=PR4\&dq=Cummings+L. + Pragmatics+A+Multidisciplinary+Perspective.+George+Square:+Edinburgh+University+Press;+ 2005.\&source=bl\&ots=JmojtkUa3o\&sig=ACfU3U07gbmhwzLI9E8x5g-UmJ7XJ9pyQ\&hl=id\&sa=X\&ved=2ahUKEwiqk7nMsMTqAhXZV30KHY6yCnUQ6AEwAHoECAo $\mathrm{QAQ} \# \mathrm{v}=$ onepage $\& \mathrm{q} \& \mathrm{f}=$ false

[6] Fransori A. Analisis Stilistika pada Puisi Kepada Peminta-Minta Karya Chairil Anwar. DEIKSIS 2017; 9 (01): 1--12. http://dx.doi.org/10.30998/deiksis.v9i01.884

[7] Kridalaksana $\quad$ H. $\quad$ Kamus $\quad$ linguistik 2008 https://play.google.com/store/books/details/Kamus Linguistik Edisi Keempat?id=gKNLDwAAQ BAJ\&hl=en US

[8] Tarigan HG. Pengajaran Gaya Bahasa. Bandung: Angkasa; 1986

[9] Keraf G. Diksi dan Gaya Bahasa. Duapuluh s. Jakarta: Gramedia Pustaka Utama; 2016.

[10] Hakim Z. Melihat Bahasa Meninjau Sastra: Sejumlah Esai Sastra. Jakarta: Departemen Pendidikan dan Kebudayaan; 1993.

[11] Mappangewa SG. Sabda Luka. Solo: Indiva Media Kreasi; 2018. 